\title{
Paduan Suara Sebagai Media Sosialisasi Program Keluarga Berencana Daerah Istimewa Yogya- karta Tahun 2011-2015
}

\author{
Suryati \\ Jurusan Musik FSP Institut Seni Indonesia Yogyakarta, telp. +628179428392; \\ e-mail: atik.jurasik@yahoo.com.
}

\begin{abstract}
The annual Family Planning (KB) March choir competition as a socialization media of governmental family planning program is held in cooperation between the Yogyakarta "Pamungkas" 072 Military Resort Command (known as the Korem 072/ Pamungkas) with the Family Planning Coordinating Board (known as the BKKBN) of Yogykarta Special Region office, to win the bullet-shaped rotating trophy provided by the Korem 072/ Pamungkas. The purpose of the competition is to socialize the "Mars KB" song in all levels of the KB program coverage territories, as well as their working patners, in order to influence the living style of families Yogyakarta through the song theme that covers the governmental programs of population, family planning, and family welfare empowerment. Although the choir competition has been carried out since 2008, this study is focused on the last 5 years events, from 2011 to 2015. This study untilized a qualitative research method that based on data collection from field studies and literature sources. The three research provlems discussed in thi study are: (1) Why chorus has been used as a medium for family planning programs dissemination; (2) how is public response to the choral competition as it is seen from the number of participants, their vocal quality, and their creative ability, which annually has increased. (3) What is the impact of these soscialization efforts toward the living style changes on Yogyakarta families as well as people understanding on the family planning programs. This study concludes that choir competition is the effectif media for this governmental progams due to the involvement of various social type of family members as seen in the participant list during the last five years. Most families in Yogyakarta are seem to agree that the successful family planning demanding equally active role from both husband and wife
\end{abstract}

Keywords: choir competition, family planning, socialization media

\begin{abstract}
Abstrak
Lomba paduan suara Mars Keluarga Berencana $(\mathrm{KB})$ sebagai media sosialisasi program KB terselenggara atas kerjasama Korem 072/Pamungkas dengan Badan Koordinasi Keluarga Berencana Nasional (BKKBN) Daerah Istimewa Yogyakarta. Diselenggarakan rutin setiap tahunnya untuk merebutkan Trophy bergilir Korem 072/ Pamungkas yang berbentuk peluru. Tujuan lomba paduan suara ini untuk mensosialisasikan Mars KB di semua Tingkat Wilayah, serta Mitra Kerja KB, sehingga program Kependudukan dan Keluarga Berencana, serta Pemberdayaan dan Kesejahteraan Keluarga pada lirik lagu tersebut dapat manjadi bagian gaya hidup keluarga di Wilayah Daerah Istimewa Yogyakarta. Penyelenggaraan lomba tersebut telah terlaksana sejak tahun 2008, akan tetapi penelitian ini difokuskan pada 5 tahun terakhir yaitu tahun 2011 hingga tahun 2015. Metode yang digunakan pada penelitian ini jenis kualitatif dengan memanfaatkan data-data yang diperoleh dari studi lapangan dan kepustakaan. Penelitian ini mengungkapkan 3 permasalahan yaitu; yang pertama mengapa paduan suara dijadikan sebagai salah satu media sosialisasi program KB. Kedua respon masyarakat terhadap lomba paduan suara terlihat dari jumlah peserta, kualitas kemampuan olah vokal dan kretivitas yang setiap tahunnya mengalami peningkatan. Ketiga dampak perubahan dan pemahaman program KB setelah terselenggaranya lomba paduan suara Mars KB sebagai media sosialisasi program KB Daerah Istimewa Yogyakarta. Penelitian ini menyimpulkan bahwa lomba paduan suara adalah media yang efektif dalam mensosialisasikan program KB karena diikuti oleh anggota keluarga dari berbagai lapisan masyarakat. Kebanyakan keluarga di Yogyakarta tampaknya setuju bahwa keberhasilan KB menuntut keseimbangan peran di antara suami dan istri.
\end{abstract}

Kata Kunci: Lomba paduan suara, keluarga berencana, media sosialisasi. 


\section{Pendahuluan}

\section{Latar Belakang}

Musik merupakan bahasa universal sebagai alat komunikasi yang efektif sebagai penyampai pesan dari komponis kepada audiens. Musik adalah perpaduan bunyi dari beberapa instrumen yang bernada teratur dan harmonis sehingga mampu membentuk irama dan lagu. Musik dapat dibedakan dalam dua hal yaitu musik instrumental dan musik vokal. Musik instrumental adalah suatu musik yang dihasilkan dari sumber bunyi instrumen, sedangkan musik vokal adalah suatu musik yang dihasilkan dari sumber bunyi pita suara manusia. Bentuk penyajian musik dapat disajikan secara solo, duet, trio, ansambel, bahkan orkestra, begitu juga dengan musik vokal dapat berbentuk paduan suara.

Paduan suara atau koor (Bahasa Belanda) merupakan salah satu jenis musik vokal yang disajikan dengan memadukan berbagai jenis suara (timbre) menjadi satu kesatuan harmoni yang utuh dan dapat mengungkapkan jiwa lagu yang dinyanyikan. Satu kelompok paduan suara memiliki anggota minimal 15 orang dan belum bisa ditentukan banyak jumlahnya, namun dapat ditentukan sesuai dengan kebutuhan, dalam penyajianya dipimpin oleh seorang dirigen. Jenis musik vokal ini banyak diminati dari berbagai kalangan yaitu; anak-anak, remaja, dewasa dan lanjut usia.

Pada umumnya suatu kelompok paduan suara membawakan musik paduan suara yang terdiri atas empat bagian suara, yaitu: sopran (suara tinggi wanita), alto (suara rendah wanita), tenor (suara tinggi pria), dan Bass (sauar rendah pria). Bila menyanyi dengan satu suara, paduan suara tersebut diistilahkan menyanyi secara unisono. Paduan suara dapat bernyanyi dengan atau tanpa iringan alat musik. Bernyanyi paduan suara tanpa iringan alat musik biasanya disebut dengan a cappella. Paduan suara dapat dikategorikan berdasarkan tiga jenis suara yaitu:

a. Paduan suara campuran yang terdiri dari suara wanita dan pria (sopran, alto, tenor, bass).

b. Paduan suara sejenis yaitu: (1) Sejenis wanita terdiri dari dua suara sopran dan altoatau tiga suara sopran,mezzo sopran, dan alto; (2) Sejenis Pria terdiri dari dua suara tenor dan bass atau tiga suara tenor, bariton, dan bass;

c. Paduan suara anak-anak biasanya terdiri dari dua suara sopran dan alto atau tiga suara sopran, mezzo sopran, dan alto, karena register suara anak-anak antara wanita dan pria masih hampir sama.

Paduan suara merupakan suatu kegiataan seni khususnya musik vokal yang berkembang sangat pesat, hal ini dapat dilihat dari banyak bermunculan kelompok paduan suara dari berbagai kalangan baik pelajar, mahasiswa, instansi-instansi, dan juga kelompok Pembinaan Kesejahteraan keluarga (PKK) maupun komunitaskomunitas yang lain. Dalam mengapresiasi kegiatan paduan suara tersebut diperlukan suatu acara, seperti lomba, festival ataupun pentas untuk ajang kompetesi atau komunikasi sosial yang dapat digunakan sebagai tolak ukur kualitas paduan suara baik dari segi olah vokal, pembawaan dan penampilan.

Dalam rangka mensosialisasikan dan menghidupkan program-program Keluarga Berencana (KB) wilayah Daerah Istimewa Yogyakarta, maka Badan Koordinasi Keluarga Berencana Nasional (BKKBN) Daerah Istimewa Yogyakarta bekerjasama dengan Korem 072/ Pamungkas untuk menyelenggarakan kegiatan lomba seni tahunan. Salah satu dari rangkaian lomba tersebut ialah lomba paduan suara Mars KB 
tingkat Daerah Istimewa Yogyakarta, untuk memperebutkan Tropy bergilir dari Korem 072/Pamungkas yang berbentuk peluru.

Tujuan diadakan lomba paduan suara ini tersebut ialah untuk mensosialisasikan Mars KB di semua Tingkat Wilayah, serta Mitra Kerja KB, sehingga program Kependudukan dan Keluarga Berencana, serta Pemberdayaan dan Kesejahteraan Keluarga yang ada dalam makna lirik lagu tersebut dapat manjadi bagian gaya hidup keluarga di Wilayah DIY. Kegiatan lomba tersebut telah berlangsung sejak tahun 2008 sebagai program tahunan yang diselenggarakan secara rutin, yang diikuti oleh masyarakat Yogyakarata dari lima kabupaten/kota yaitu; Sleman, Bantuk, Kulon Progo, Gunung Kidul dan Kota Yogyakarta.

Suatu program tersebut dapat diterima masyarakat dan berhasil dengan baik memerlukan suatu proses yang panjang. Langkah awal dari program tersebut perlu adanya sosialisasi yang baik dan menarik bagi masyarakat lingkungannya, agar dapat tersampaikan tepat sasaran pada masyarakat dari pedesaan hingga perkotaan. Pada eraglobalisasi dan informasi teknologi yang semakin meningkat, maka sosialisasi Program KB dapat dilakukan dengan berbagai macam bentuk media. Media adalah segala sesuatu yang dapat dipergunakan untuk merangsang pikiran, perasaan, perhatian bagi orang lain. Menurut Winataputra (2007) media berasal dari bahasa latin merupakan kata jamak dari "Medium" yang secara harfiah berarti "perantara" (between), yaitu perantara sumber pesan (source) dengan penerima pesan (receiver). Perantara dapat dikatakan sebagai jembatan untuk mencapai tujuan. Jika media (perantara) dapat merangsang dan menarik perhatian masyarakat, maka sosialisasi tersebut akan lebih mudah untuk diterima.
Berkaitan dengan hal di atas, maka untuk mengapresiasikan kegiatan tersebut BKKBN Daerah Istimewa Yogyakarta menyelenggarakan lomba paduan suara, sebagai wadah atau ajang kompetisi dan ekspresi seni khususnya seni musik. Dalam pelaksanaan lomba tersebut setiap peserta diwajibkan untuk membawakan satu lagu wajib "Mars KB" dan satu lagu pilihan bebas dari lagu-lagu daerah. Melalui syair lagu "Mars KB" yang dibawakan para peserta paduan suara dapat digunakan untuk menyampaikan pesen dari sang komponis kepada audience.

Setiap kelompok paduan suara menggaungkan lagu tersebut bertujuan untuk membangkitkan kembali program KB dan juga sebagai media untuk mensosialisasikan dan membangun komitmen program KB baik lingkungan Pemerintah Kota Yogyakarta maupun di kalangan masyarakat Yogyakarta. Selain itu untuk mensosialisasikan lagu-lagu daerah kepada masyarakat Yogyakarta. Tidak kalah pentingnya kegiatan tersebut juga sebagai ajang kompetisi pertunjukkan paduan suara yang saling menonjolkan kebolehannya baik dari kemampuan berolah vokal suara maupun pembawaan, serta penampilan yang diwarnai dengan berbagai macam koreografinya.

Peserta lomba tersebut banyak diikuti dari kelompok-kelompok PKK, Mahasiswa, dan isntansi-instansi terkait dari seluruh Daerah Istimewa Yogyakarta lima kabupaten/kota, yaitu Sleman, Bantul, Kulon Progo, Gunung Kidul, dan Yogyakarta. Setiap kabupaten/kota selalu mengirimkan perwakilan untuk mengikuti lomba tersebut. Setidaknya dalam mensosialisasikan program KB di seluruh daerah Yogyakarta dapat terwakilkan dari masing-masing peserta tersebut. Oleh karena itu paduan suara dapat berperan sebagai sarana komunikasi sosial dalam mensosialisasikan 
suatu program kepada masyarakat lingkungannya.

Dalam kegiatan lomba tersebut peneliti selalu ikut berperan aktif untuk menyaksikan dan mengamati sebagai salah satu juri lomba paduan suara sejak tahun 2010 hingga 2014. Selama lima tahun berturut-turut peneliti mengamati lomba tersebut setiap tahunnya mengalami peningkat-an, baik dari kualitas paduan suara maupun peserta paduan suara. Selain itu terlihat antusias para peserta yang ingin memperlihatkan kemampuannya masingmasing kelompok, untuk siap bertanding, yang setiap tahunnya meningkatkan kreativitasnya dalam meraih kemenangannya.

Peningkatan peserta lomba tersebut berdampak pada antusias masyarakat pendukungnya maupun audience untuk ingin menyaksikan dan mensuport jagoannya masing-masing. Oleh karena itu peneliti mengamati bahwa semakin meningkatnya peserta lomba paduan suara, maka akan semakin banyak pula masyarakat pendukungnya. Berkaitan dengan hal tersebut, maka tertarik untuk diteliti agar dapat mengungkapkan beberapa permasa-lahan yang ada. Namun sesuai dengan latar belakang tersebut, penelitian ini akan dibatasi pada kegiatan lomba 5 tahun terakhir yang dilaksanankan pada tahun 2011 hingga 2015.

\section{Metode Penelitian}

Penelitian ini menggunakan deskriptif analisis dengan memanfaatkan data kualitatif. Dalam penelitian kualitatif seorang peneliti dituntut harus mampu mengeksplanasikan semua bagian yang dipercaya dari sumber informasi yang diketahuinya serta tidak menimbulkan kontradiksi dengan interpretasi yang disajikan. Adapun metode yang digunakan adalah pendekatan multidisipliner yaitu; musikologis dengan ditunjang dengan konsep-konsep historis, sosiologi, dan antropologi. a. Bahan atau Materi

Objek penelitian adalah para peserta lomba paduan suara dan masyarakat pendukungnya serta Badan Koodinasi Keluarga Berencana Nasional (BKKBN) Derah Istimewa Yogyakarta sebagai pihak penyelenggara. Peneliti mengambil sampel dari beberapa anggota peserta paduan suara yang berperan sebagai media sosialisasi dan masyarakat pendukungnya atau audiens sebagai respon terhadap lomba yang berkaitan dengan progam Keluarga Berencana.

b. Alat Bantu

Alat untuk membantu dalam mengungkapkan permasalahan pada penelitian ini adalah alat tulis, dokumentasi baik untuk perekaman ataupun mengambil gam-bar (foto) pada saat pelaksanaan lomba paduan suara Mars KB berlangsung dapat berupa camera dan handycam.

c. Jalan Penelitian

Penelitian ini menyelusuri dari permasalahan yang dihadapi oleh BKKBN Daerah Istimewa Yogyakarta dalam menggalakkan Program KB, dan respon masyarakat terhadap program tersebut. Pengamatan dilakukan secara langsung di lapangan pada waktu kegiatan lomba paduan suara Mars KB berlangsung melalui para peserta lomba paduan suara dan audience di Halaman BKKBN Daerah Istimewa Yogyakarta, Pendapat Wiyatapraja Komplek Kepatihan, Danurejan Yogyakarta, dan di Sasana Wiratama, Monumen Diponegoro, Tegalrejo, Yogyakarta.

\section{d. Variabel}

Variabel yang dipelajari diantaranya para peserta paduan suara, tujuan lomba paduan suara, respon masyarakat terhadap lomba, dampak program KB terhadap masyarakat setelah diadakan lomba paduan suara. 
e. Prosedur Pelaksanaan

Penelitian ini secara kronologis dapat dilakukan melalui beberapa tahapan yaitu studi lapangan (observasi), wawancara, studi pustaka, dan analisis data. Penelitian studi lapangan dilakukan untuk mendapatkan data-data tentang objek yang diteliti melalui observasi, wawancara dengan mengajukan pertanyaan-pertanyaan kepada nara sumber atau informan, dan perekaman. Observasi ditujukan kepada peserta lomba serta masyarakat pendukungnya pada waktu pelaksanaan lomba paduan suara Mars KB secara langsung di BKKBN Kota Yogyakarta.

Selanjutnya untuk memperoleh datadata yang tidak dapat dilakukan melelui observasi, maka dilakukan wawancara langsung kepada panitia penyelenggara dan koordinator pesesrta lomba. Kemudian untuk mendukung kepentingan dalam pembahasan dilakukan perekaman secara audio visual pada pelaksanaan lomba paduan suara Mars KB tersebut.

\section{f. Analisis Data}

Analisis data diperoleh baik dari hasil observasi, wawancara, pencatatan dokumen, studi kepustakaan, dan hasil informan yang dianalisis secara kualitatif. Data-data yang terkumpul tersebut dikelompokkan sesuai dengan permasalahan yang dihadapi. Selanjutnya data tersebut disusun dalam kategori-kategori tertentu untuk mengacu pada pokok-pokok bahasan yang teleh ditentukan dalam penelitian. Data-data penelitian yang meliputi data musikal, pengamatan dan informasi yang terdapat pada lomba paduan suara Mars KB ini dianalisis dengan menggunakan pendekatan musikologi, sosiologi, historis dan antropo-logi.

\section{Pembahasan}

\section{Paduan Suara dan Media Sosialisasi KB}

Korem 072/Pamungkas bekerjasama dengan Badan Koordinasi Keluarga Berencana Nasional (BKKBN) Daerah Istimewa
Yogyakarta menyelenggarakan lomba paduan suara Mars KB, yang dilaksanaan setiap bulan Juni, bertepatan dengan hari Keluarga. Kerjasama penyelenggaraan tersebut sudah berlangsung sejak tahun 2008, kegiatan ini secara rutin diselenggarakan setiap tahun. Ketua Panitia Lomba Siswatiningsih mengatakan tujuan diadakan lomba paduan suara itu untuk mensosialisasikan Mars KB di semua tingkat wilayah dan mitra kerja KB.

BKKBN memilih Paduan suara sebagai salah satu media sosialisasi progam KB, karena paduan suara merupakan salah satu wadah bakat seni suara secara kelompok yang sudah berkembang dan menyebar di seluruh wilayah baik dilingkungan masyarakat Desa, Instansi dan Perguruan Tinggi memiliki kelompok paduan suara. Di samping itu paduan suara juga suatu kegiatan sebagai aktivitas sosial yang selama ini telah dikenal dekat dengan masyarakat, yang sudah banyak terbentuk di seluruh kalangan baik dari kalangan anak-anak, remaja, dewasa dan lanjut usia. Bentuk penyajian paduan suara disajikan secara kelompok dengan melibatkan banyak orang. Oleh karena itu dengan memilih lomba paduan suara sebagai sosialisasi program KB di seluruh wilayah Daerah Istimewa Yogyakarta, setidaknya program tersebut dapat tersampaikan melalui para peserta lomba paduan suara beserta masyarakat penukungnya.

Penyelenggaraan Lomba Paduan Suara dengan lagu wajib Mars KB tersebut, dalam rangka mensosialisasikan dan membangkitkan kembali Porgram KB di tengahtengah masyarakat saat ini, berbagai cara dan upaya telah dilakukan oleh Kantor Keluarga Berencana Kota Yogyakarta yaitu selain melakukan Advokasi, pendekatan kepada para pemegang kebijakan, tokohtokoh formal maupun informal, juga melakukan Komunikasi Informasi dan Edukasi (KIE) kepada masyarakat luas dibantu oleh para pengelola program KB. Berbagai macam bentuk KIE yang dianggap 
sangat efektif adalah melalui musik/lagu yaitu dalam bentuk lomba paduan suara. Maksud dan tujuan daripada pelaksanaan Lomba paduan suara tersebut adalah sebagai media untuk mensosialisasikan dan membangun komitmen program KB baik lingkungan Pemerintah Kota Yogyakarta maupun di kalangan masyarakat Kota Yogyakarta dan untuk menggaungkan kembali lagu Mars KB.

Lomba ini dilaksanakan sebagai langkah proses Advokasi dan Komunikasi Informasi dan Edukasi (KIE) pada masyarakat, yang memiliki kecenderungan berdampak langsung pada masyarakat. Proses KIE ini diharapkan dapat memberikan sumbangan yang berarti dalam menyentuh aspek kesadaran dan sikap kearah perubahan perilaku dari kondisi yang belum mau menjadi akseptor $\mathrm{KB}$ menjadi mau ber $\mathrm{KB}$ dengan menggunakan kontrasepsi modern terutama yang jangka panjang.

Cara penyampaian KIE yang tepat kepada masyarakat luas adalah melalui pendekatan-pendekatan yang mudah untuk diingat dan berisi motivasi untuk kearah yang lebih baik. Salah satu upaya yang dilaksanakan secara rutin setiap tahun oleh Perwakilan BKKBN Daerah Istimewa Yogyakarta adalah penyelenggaraan Lomba Paduan Suara dengan lagu wajib Mars KB dan lagu daerah Jawa sebagai lagu pilihan. Lirik lagu yang mudah diingat dan dihafal serta maknanya mengandung motivasi kehidupan yang baik, diharapkan dapat menjadi dorongan bagi keluarga-keluarga Indonesia melaksanakan program-program pemerintah. Program-program tersebut dalam hal ini ialah Kependudukan dan KB, dan Pembangunan Keluarga (1' bagi pelaksana dan pengelola Program KKBPK yang mempunyai tujuan dan komitmen yang sama untuk memberikan pendampingan pada keluarga guna mewujudkan keluarga yang bahagia dan sejahtera.
Kepala BKKBN Daerah Istimewa Yogyakarta Dra. Hitima Wardhani, M.Ph., mengatakan bahwa dalam lomba Paduan suara ini tidak hanya diikuti oleh kelompok Paduan Suara ibu-ibu saja, tetapi juga diikuti oleh Kelompok Paduan Suara campuran bapak-bapak dan ibu-ibu dari berbagai Instansi, bahkan banyak juga dari kalangan Mahasiswa yang merupakan usia muda yang produktif. Hadirnya banyak paduan suara mahasiswa dari berbagai kampus, mewarnai penyelenggaraan lomba tahun ini, sehingga generasi muda pun sudah mulai teradvokasi mengenai program ini. Hal ini penting karena mereka merupakan calon Pasangan Usia Subur (PUS) di masa mendatang.

Lebih lanjut dikatakan oleh ibu Siswatiningsih bahwa penyelenggaraan sosialisasi program KB diberharapkan tidak berhenti pada lomba paduan suara saja. Akan tetapi masyarakat makin menyadari pentingnya mengikuti program ini karena besar manfaatnya sebagaimana terkandung dalam lirik di kedua lagu tersebut. Hal yang sama dikatakam dalam sambutan DanRem 072 yang diwakili oleh Letkol Arm Indro Respati mengatakan bahwa dengan diadakan lomba ini diharapkan isi dari mars KB akan tertanam dalam sanubari peserta terutama yang masih muda, sehingga program KB kedepan akan semakin sukses dalam menciptakan keluarga yang sejahtera sebagai generasi penerus bangsa.

Di samping itu BKKBN Daerah Istimewa Yogyakarta menyelenggarakan lomba paduan suara bertujuan sebagai ajang bagi kelompok-kelompok paduan suara yang ada di lingkungan Yogyakarta untuk berkompetisi, mengembangkan kemampuan dan kreativitasnya dalam berolah vocal, dan diharapkan peserta lomba paduan suara tidak hanya hafal lagu namun juga mampu menghayati sehingga nantinya bisa ikut serta mensosialisasikan program $\mathrm{KB}$ kepada masyarakat di lingkungan wilayah tempat 
tinggalnya.Marjin semua heading sub bahasan (Pemndahuluan, Pembahsan, Penutup, dan Referensi) dibuat rata kiri.

\section{Respon Masyarakat terhadap Lomba}

Respon masyarakat Daerah Istimewa Yogyakarta terhadap pelaksanaan lomba paduan suara Mars KB dapat dikatakan sangat antusias dan menyambut dengan baik. Hal ini dapat dilihat dari jumlah peserta lomba paduan suara yang mengalami peningkatan dari setiap tahunnya yang diikuti dari berbagai mitra kerja, instansi dan Perguruan Tinggi. Pelaksanaan lomba tersebut berlangsung sejak tahun 2008, akan tetapi peneliti membatasi untuk melihat perkembangan penyelenggaraan kegiatan lomba paduan suara selama 5 tahun terakhir, mulai dari tahun 2011 hingga tahun 2015, dikarenakan peneliti terlibat langsung sebagai juri lomba tersebut.

Pada tahun 2011 pelaksanaan lomba paduan suara Mars KB pada hari Rabu, 22 Juni 2011, di halaman kantor BKKBN Kota Yogyakarta, yang dimulai dari jam 09.00 hingga jam 13.00. Adapun lomba tersebut diikuti 12 kelompok yang terdiri dari mitra kerja, Instansi terkait dan Mahasiswa, dari 12 kelompok tersebut menunjukkan kebolehannya melalui kemampuan berolah vokal kreativitasnya masing-masing. Dalam kompetisi tersebut diambil 5 kejuaraan, dengan perincian Juara I, II, III dan Harapan I dan II serta diambil 1 dirigen terbaik.

Pada tahun 2012 lomba paduan suara Mars KB dilaksanakan pada hari Rabu, 13 Juni 2012, bertempat di halaman kantor BKKBN Kota Yogyakarta, yang dimulai dari jam 09.00 hingga jam 14.00. Adapun lomba tersebut diikuti 20 kelompok yang terdiri dari mitra kerja, Instansi terkait dan Mahasiswa. Menurut pengamatan penulis dari 20 kelompok tersebut mengalami peningkatan dalam hal kemampuan berolah vokal dan kreativitas pembawaan serta penampilan baik dari segi koreografi maupun perpaduan kontumnya. Dalam kompetisi tersebut seperti sebelumnya diambil 5 kejuaraan, dengan perincian Juara I, II, III dan Harapan I dan II serta diambil 1 dirigen terbaik. Pada tahun 2012 ini respon masyarakat terhadap lomba paduan suara Mars KB sangat antusias dan mengalami peningkatan tajam terutama dari jumlah peserta yang bertambah 8 kelompok dibanding tahun 2011. Bertambahnya jumlah peserta lomba, maka bertambah juga jumlah masyarakat pendukungnya.

Pada tahun 2013 pelaksanaan lomba paduan suara Mars KB pada hari Selasa, 18 Juni 2013, bertempat di halaman kantor BKKBN Kota Yogyakarta, dari jam 09.00 hingga jam 14.00. Lomba diikuti 17 kelompok, terdiri dari mitra kerja, instansi terkait dan Mahasiswa. Kualifikasi juara meliputi Juara I, II, III, dan Harapan I dan II serta diambil 1 dirigen terbaik. Jika dilihat dari kualitas kemampuan berolah vokal dan kreativitas peserta lomba setiap tahunnya mengalami peningkatan. Pada tahun 2013 sedikit mengalami penurunan, dikarenakan beberapa undangan yang disampaikan dari pihak penyelenggara terlambat.

Pada tahun 2014 pelaksanaan lomba paduan suara Mars KB pada hari Rabu, tanggal 26 Februari 2014, bertempat di Pendapa Wiyatapraja Komplek Kepatihan, Danurejan Yogyakarta, yang dimulai dari jam 09.00 hingga jam 14.00. Adapun lomba tersebut diikuti 26 kelompok, terbagi dua kategori masing-masing untuk paduan suara Mars KB berjumlah 21 peserta dan Mars PKK berjumlah 5 peserta.

Pada tahun ini dari 21 kelompok paduan suara Mars KB diambil 6 kejuaraan, dengan perincian Juara I, II, III dan Harapan I, II dan III serta diambil 1 dirigen terbaik, sedangakan 5 kelompok paduan suara Mars PKK masing-masing mendapatkan Juara I, II, III dan Harapan I dan II serta 1 dirigen terbaik. 


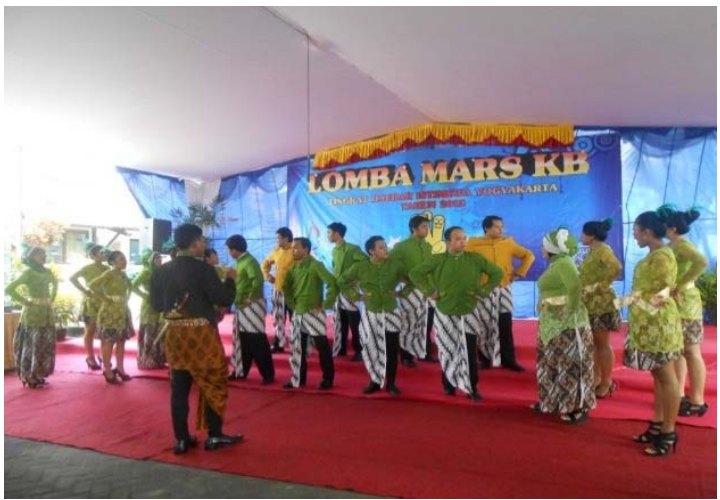

Gambar 1: Juara I peserta lomba Paduan suara tahun 2013.

Penyelenggaraan lomba paduan suara pada tahun-tahun sebelumnya biasanya dilaksanakan pada bulan Juni, namun pada tahun ini berbeda pelaksanaannya diajukan pada bulan Februari. Penyelenggaraan ini atas permintaan ketua tim penggerak PKK Daerah Istimewa Yogyakarta GKR Hemas, untuk mennyambut Hari Kesatuan Gerak PKK agar pelaksanaan lomba paduan suara Mars KB dilaksanakan bersamaan dengan paduan suara Mars PKK. Hal ini dilakukan karena masih ada kelompok masyarakat yang kurang mendukung atau menerima norma keluarga kecil. Tujuannya antara lain tersosialisasikannya kembali slogan Dua Anak Cukup dan meningkatkan pencapaian keserataan KB. Pada tahun 2014 ini antusias dan respon masyarakat terhadap lomba paduan suara sangat nampak dari jumlah peserta dan masyarakat pendukungnya, karena dari dua kategori. Akan tetapi masih nampak jelas pada kategori Mars KB, dikarenakan peserta tidak terbatas dari kelompok ibu-ibu PKK.

Pada tahun 2015 pelaksanaan lomba paduan suara Mars KB pada hari Kamis, tanggal 11 Juni 2015, bertempat di Sasana Wiratama, Monumen Diponegoro, Tegalrejo, Yogyakarta, yang dimulai dari jam 09.00 hingga jam 13.00. Adapun lomba tersebut diikuti 15 kelompok yang terdiri dari mitra kerja, Instansi terkait dan Mahasiswa, dari 15 kelompok tersebut diambil 5 kejuaraan, dengan perincian Juara I, II, III dan Harapan I dan II serta diambil 1 dirigen terbaik. Jika dilihat dari kualitas kemampuan berolah vokal dan kreativitas peserta lomba setiap tahunnya mengalami peningkatan, namun pada tahun ini sedikit mengalami menurunan.

Adapun salah satu foto peserta lomba paduan suara tahun 2015 sebagai berikut:

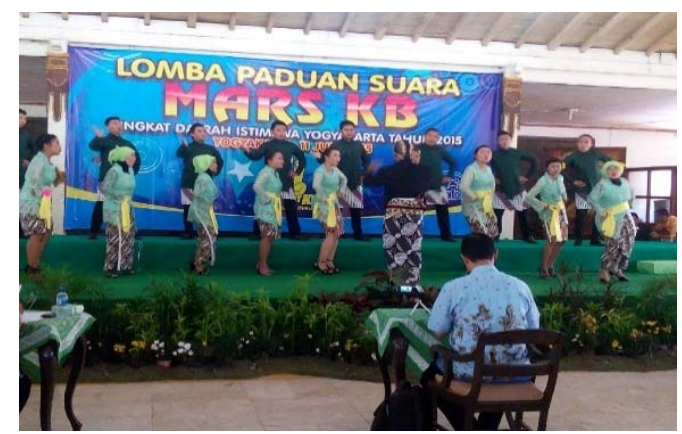

Gambar 2: Salah satu peserta lomba paduan suara tahun 2015

Respon masyarakat terhadap lomba paduan suara juga sedikit mengalami penurunan. Menurut pengakuan Hasan sebagai ketua penyelenggara beserta beberapa peserta paduan suara, bahwa undangan pelaksanaan lomba tersebut sudah terlalu dekat dengan hari pelaksanaan diperkirakan undangan sampai ke tempat tujuan baik dari mitra kerja, instansi terkait maupun Perguruan Tinggi satu minggu sebelum hari pelaksanaan. Oleh karena itu dengan pendeknya jangka waktu tersebut beberapa mitra kerja, instansi terkait ataupun Perguruan Tinggi tidak berani untuk spekulasi mengikuti lomba paduan suara Mars KB.

Berdasarkan pemaparan diatas, maka pelaksanaan lomba paduan suara "Mars KB" tahun 2011 hingga 2015 dapat tersusun pada tabel sebagai berikut:

Tabel 1. Jumlah peserta 2011-2015

\begin{tabular}{|c|l|l|l|c|}
\hline NO & $\begin{array}{l}\text { Hari, } \\
\text { Tgl-Bln-Th }\end{array}$ & Waktu & Tempat & $\begin{array}{l}\text { Jml } \\
\text { Peserta }\end{array}$ \\
\hline 1. & $\begin{array}{l}\text { Rabu, } \\
22 / 6 / 2011\end{array}$ & $\begin{array}{l}09.00- \\
13.00\end{array}$ & $\begin{array}{l}\text { Halaman BKKBN } \\
\text { Yogyakarta }\end{array}$ & 12 \\
\hline
\end{tabular}




\begin{tabular}{|c|l|l|l|c|}
\hline 2. & $\begin{array}{l}\text { Rabu, } \\
13 / 6 / 2012\end{array}$ & $\begin{array}{l}09.00- \\
14.00\end{array}$ & $\begin{array}{l}\text { Halaman BKKBN } \\
\text { Yogyakarta }\end{array}$ & 20 \\
\hline 3. & $\begin{array}{l}\text { Selasa, } \\
18 / 6 / 2013\end{array}$ & $\begin{array}{l}09.00- \\
14.00\end{array}$ & $\begin{array}{l}\text { Halaman BKKBN } \\
\text { Yogyakarta }\end{array}$ & 17 \\
\hline 4. & $\begin{array}{l}\text { Rabu, } \\
\end{array}$ & $\begin{array}{l}09.00- \\
14.00\end{array}$ & $\begin{array}{l}\text { Pendapa } \\
\text { Wiyatapraja } \\
\text { Komplek } \\
\text { Kepatihan }\end{array}$ & $\begin{array}{l}\text { 21 “Mars } \\
\text { KB” dan } \\
\text { “"Mars } \\
\text { PKK" }\end{array}$ \\
\hline 5. & $\begin{array}{l}\text { Kamis, } \\
11 / 6 / 2015\end{array}$ & $\begin{array}{l}09.00- \\
13.00\end{array}$ & $\begin{array}{l}\text { Monumen } \\
\text { Diponegoro, Te- } \\
\text { galrejo }\end{array}$ & 15 \\
\hline
\end{tabular}

\section{Pemahaman masyarakat tentang KB}

Dampak setelah terselenggaranya lomba paduan suara Mrs KB tersebut, masyarakat di wilayah Daerah Istimewa Yogyakarta terutama peserta paduan suara beserta pendukungnya diharapkan akan memahami arti penting KB melalui lirik Mars KB yang selalu dikumandangkan. Menurut Susilowati salah satu anggota paduan suara dari istri bhayangkari 403 Kentungan mengatakan bahwa mengikuti lomba paduan suara tidak hanya sekedar menyanyi, tetapi dapat menghayati dan memahami makna lirik lagu. Menurutnya dengan menyanyi bisa menjadi sehat, senang, bahagia dapat berekspresi, komunikasi melalui lagu-lagu yang dinyanyikan. Lebih lanjut dikatakan pemahaman tentang KB sendiri tidak hanya terpaku pada alat kontrasepsi, namun membentuk keluarga kecil yang bahagia, sehat, tentram, sejahtera dan mandiri sesuai makna lirik lagu Mars KB. Adapun lirik lagu Mars KB adalah sebagai berikut:

\section{Keluarga Berencana sudah waktunya, \\ Janganlah diragukan lagi, \\ Keluarga berencana besar maknanya, \\ Untuk hari depan nan jaya, \\ Putra putri yang sehat, cerdas dan kuat, \\ Kan menjadi harapan bangsa, \\ Ayah ibu bahagia, rukun raharja \\ Rumah tangga tentram sentosa".}

Lirik lagu Mars KB dalam lomba paduan suara selain untuk sarana komunikasi dan sosialisasi juga menumbuhkan kesadaran pada masyarakat bahwa keberhasilan program KB tersebut tidak lepas dari peran dan partisipasi aktif wanita atau istri yang dengan sukarela menggunakan alat kontrasepsi untuk tujuan mengatur jarak kelahiran atau menghentikan kelahiran. Namun dengan adanya perubahan paradigma menuntut adanya perubahan program terutama dengan menjamin kualitas pelayanan keluarga berencana dan kesehatan reproduksi yang lebih baik dan keadilan gender melalui pemberdayaan wanita serta peningkatan partisipasi pria.

Meningkatnya partisipasi pria dalam ber-KB dan terwujudnya keadilan dan kesetaraan gender diharapkan dapat memberikan kontribusi terhadap pengendalian pertumbuhan penduduk dan penanganan masalah kesehatan reproduksi, serta meningkatkan status kesehatan wanita dan akhirnya berdampak terhadap penurunan angka kematian ibu, bayi dan anak.

Oleh karena itu para anggota paduan suara tidak hanya terbatas pada kelompok paduan suara sejenis atau perempuan saja, akan tetapi paduan suara campuran wanita dan pria. Hal ini dilakukan agar dapat dipahami oleh para suami atau pria bahwa jenis KB pria ini ternyata masih dapat dikatakan kurang berhasil jika dibandingkan dengan jenis KB untuk wanita, hal ini ditunjukan dengan jumlah kesertaan pria yang relatif masih rendah. Angka partisipasi pria secara langsung dalam program KB masih rendah baik dalam tingkat nasional ataupun daerah.

Rendahnya angka partisipasi pria dalam ber-KB ini disebabkan oleh berbagai faktor. Beberapa studi yang dilakukan ternyata penyebab rendahnya partisipasi pria dalam ber-KB anatara lain: (1) pilihan/jenis kontrasepsi pria terbatas, (2) sasaran KIE dan konseling lebih kepada perempuan, (3) belum optimalnya provider untuk memberikan pelayanan kontrasepsi pria, (4) faktor sosial budaya serta dukungan politis dan operasional yang masih terbatas yang menganggap $\mathrm{KB}$ dan kesehatan reproduksi serta kesehatan ibu dan anak adalah urusan 
perempuan, (5) pengetahuan dan kesadaran pria dalam pemakaian kontrasepsi masih rendah (BKKBN Kota Yogyakarta).

Hal ini sangat disadari dan dipahami oleh masyarakat Daerah Istimewa Yogyakata, bahwa ber- KB membutuhkan partisipasi peran aktif baik dari wanita maupun pria tanpa adanya peran aktif keduanya program KB tidak akan berhasil dengan baik dan seimbang. Selanjutnya pemahaman ini diharapkan dapat tertanam dalam sanubari para peserta paduan suara campuran wanita dan pria terutama para mahasiswa sebagai generasi muda, agar program KB ke depan akan lebih maju semakin sukses menciptakan keluarga bahagia, sejahtera sebagai generasi penerus bangsa.

\section{Penutup}

Berdasarkan uraian hasil penelitian yang dicapai, maka dapat disimpulkan bahwa dengan pelaksanaan lomba paduan suara Mars KB yang terselenggara atas kerjasama Korem 072/Pamungkas dengan BKKBN Daerah Istimewa Yogyakarta. Lomba tersebut dilaksanaan secara rutin setiap tahun sekali bertepatan dengan Hari Keluarga untuk merebutkan Trophy bergilir dari Danrem 072/Pamungkas yang berbentuk peluru.

Badan Koordinasi Keluarga Berencana Nasional memilih Paduan suara sebagai media sosialisasi $\mathrm{KB}$, menganggap melalui seni khususnya musik vokal/ bernyanyi secara kelompok (paduan suara) salah satu musik yang tepat. Hal ini dikarena paduan suara sudah banyak diminati dan dimiliki di setiap instansi dan Perguruan Tinggi. Di samping itu anggota paduan suara akan melibatkan banyak orang selain para peserta juga para pendukungnya, sehingga dengan mudah partisipasi masyarakat banyak program sosialisasi program $\mathrm{KB}$ akan tersampaikan melalui lagu "Mars" KB.

Penyelenggaraan lomba paduan suara “Mars KB" selama 5 tahun terakhir sejak ta- hun 2011 hingga tahun 2015, respon masyarakat terhadap lomba tersebut dapat dilihat dari antusias dan semangat, serta jumlah peserta dari setiap tahunya. Berdasarkan data hasil penelitian yang dicapai pada umumnya lomba paduan suara setiap tahunnya mengalami peningkatan baik dilihat dari jumlah peserta, kualitas kemampuan berolah vokal, pembawaan yang diwarnai dengan koreografi dan penampilan kostum yang selalu berganti-ganti membuat semaraknya acara kegiatan lomaba tersebut. Hal ini disadari oleh para peserta bahwa lomba paduan suara selain sebagi media sosialisasi program $\mathrm{KB}$, juga sebagai ajang kompetisi sehingga berlomba-lomba untuk menunjukkan kualitas kemampuan berolah vokal dan kreativitasnya masing-masig.

Dampak pemahaman program KB setelah disosialisasikan melalui lomba paduan suara Mars KB, maka masyarakat Daerah Istimewa Yogyakarta akan memahami arti penting KB melalui lirik Mars KB yang selalu dikumandangkan. Pemahaman tentang $\mathrm{KB}$ sendiri tidak hanya terpaku pada alat kontrasepsi, namun membentuk keluarga kecil yang bahagia, sehat, tentram, sejahtera dan mandiri. Hal ini disadari dan dipahami oleh masyarakat Daerah Istimewa Yogyakata, bahwa ber- KB membutuhkan partisipasi peran aktif baik dari wanita maupun pria tanpa adanya peran aktif keduanya program KB tidak akan berhasil dengan baik dan seimbang

\section{Referensi}

Atmodjo, Soebronto K, 1985, Memimpin Paduan Suara, BPK Gunung mulia, Jakarta.

Burke, Peter, 2003, Sejarah dan Teori Sosial, Yayasan Obor Indonesia, Jakarta. 
Dahrendorf, R, 1964, "Homo Sociologigus", dalam Essays in the Theory of Society, London.

Edi Sediyawati dan Sapardi Joko Damono, 1983, Seni Dalam Masyarakat Indonesia, Gramedia, Jakarta.

Kellner, Douglas, 1995, Media Culture: Cultural studies, identity and politic between the modern and the postmodern, London, New York.

Koentjaraningrat, 1974, Kebudayaan, Manusia dan Pembangunan, Jakarta: Gramedia.

Merriam, Alan P., 1964, The Antrophology of Music, Chicago: North Western University Press,.

Moleong, L.J., 1999, Metodologi Penelitian Kualitatif, Bandung: PT. Rosda Karya.

Prier, Karl-Edmund,1991, Sejarah Musik Jilid I, Yogyakarta: Pusat musik Liturgi.
2011, Kamus Musik, Cetakan ke dua, Yogyakarta: Pusat Musik Liturgi.

Randel, D.M, 1999, The Harvard Concise Dictionary of Music And Musician, New York: Harvard University Press Reference Library.

Sitompul Binsar, 1988, Paduan Suara dan Pemimpinnya, PT. Jakarta: BPK Gunung Mulia.

Soedarsono, R.M., 1999, Metodologi Penelitian Seni Pertunjukan dan Seni, Bandung: Masyarakat Seni Pertunjuk-an Indonesia.

Tim Pusat Musik Liturgi, 2009, Menjadi Dirigen III, "Membina Paduan Suara", Yogyakarta: Pusat Musik Liturgi. 